\title{
Playing with/as Systems: Short Paper, Discussion and Demonstration
}

\author{
Michael Straeubig \\ CogNovo \\ Plymouth University, UK \\ michael.straeubig@plymouth.ac.uk
}

Received 17 April 2017; accepted 26 September 2017; published 21 November 2017.

\begin{abstract}
Complex phenomena such as play, creativity or innovation are familiar, yet difficult to describe in a systematic manner. In this short article I propose six necessary conditions for any comprehensive description of play. Against this background I discuss my systems-theoretic, constructivist and practice-informed approach to play.
\end{abstract}

Keywords: cybernetics; distinctions; game studies; play; systems theory.

\section{Play}

Play is a complex and interesting phenomenon. It is a common experience, yet mysterious and paradoxical in nature. It is free but functional, frivolous but meaningful, cultural (Huizinga, 1955) but pre-human (Burghardt, 2005). From our early childhood we engage in play, but we are far from a firm understanding of it. Various disciplines such as psychology, sociology, anthropology, ethology, cognitive science and the humanities have made attempts to explain and conceptualize play through numerous conflicting theories (Ellis, 1973; Henricks, 2008). Play is also linked to wellbeing, creativity and innovation (Bateson \& Martin, 2013). However, approaches that attempt to instrumentalize play have been met with mixed responses from the community of play thinkers and practitioners. Some argue that play should be regarded an autotelic activity, exercised for its own sake and not for any extrinsic purposes (Sicart, 2014). Yet designers of games and playful experiences ${ }^{1}$ increasingly make use of experimental findings from psychology and cognitive sciences in order to aid them in creating compelling play experiences.

\footnotetext{
1 There are various ways to draw distinctions between games (Salen \& Zimmerman, 2003, pp. 70-83) and play (Salen \& Zimmerman, 2003, pp. 300-311); for example, one can observe games as media that are particularly suited for forms of play to appear (Luhmann, 2000).
} 


\section{Descriptions}

A fundamental theory that would be capable of describing these multiple facets of play currently does not exist. This has been problematized (Sutton-Smith, 1997), however, a solution has not been proposed so far. I argue that any comprehensive description of play needs to meet at least six conditions:

The first condition is an adequate level of abstraction. The description has to be abstract and general enough to cover the wide range of phenomena that are observable as play: free play between children; the ritual of a sports match; non-human (e.g., animal) play; the drama unfolding during a game of chess; metarules emerging from a multiplayer online battle; unpleasant, forced, and dark play (Mortensen, Linderoth, \& Brown, 2015); or the experiential quality of a playful encounter between adults. These and many other phenomena have to be considered within a description of play. This high grade of abstraction requires a simple, universal foundation.

The second condition is sufficient complexity: the description has to be complex enough to account for the complexity of play. Note that this and the previous condition act in an antagonistic manner in that high abstraction pulls in the direction of simplicity, while complexity is required to describe a complex phenomenon. This rules out simplistic general explanations in the style of "play is getting rid of surplus energy" (Spencer, 1855) or "play is capitalism" (Nash \& Penney, 2015). Throughout the nineteenth and twentieth centuries, many attempts to explain play by single causes have been put forward (Ellis, 1973), a development that can itself be observed as an artefact of the social sciences (Luhmann, 2009).

The third condition is that it has to account for paradoxical and contradictory findings. Is play a biological function to practice useful behavior (Pellis, Pellis, \& Bell, 2010), or is it an ambiguous phenomenon that is best described in the form of seven cultural rhetorics (Sutton-Smith, 1997)? One way to make sense of such a contradiction is to include its context in the description. For example, one may choose to not only describe the conflicting observations, but also the observers that are involved. If animals play and if ethologists postulate play as a biological function, we can observe (and explain) this fact because ethology is based on functional explanations. ${ }^{2}$ Therefore, a clash with, for example, Huizinga (1955), who posited play as deeply cultural, can be avoided if we carry the context with us. Again, we have relocated our observation from play itself to the scientific system, but we are aware of this shift of perspective. When we talk about a theory of play, we talk about a social system that is different from play, except when we are playing with the theory itself.

\footnotetext{
2 Maturana and Varela (1980) calls this phenomenon "structural determinism."
} 
From the previous remarks follows the fourth condition: a comprehensive description of play must be transdisciplinary. While acknowledging disciplinary foundations and methodologies, it has to provide a critical analysis of traditional approaches and must be able to transcend them (Punt \& Blassnigg, 2013). This means that there cannot be all-encompassing, mono-thematic explanations that are rooted within a specific discipline or theory like biology, child development or Marxism.

The fifth condition is Anschlussfähigkeit (connective capability), a term borrowed from Luhmann's theory that denotes an important characteristic of social systems. Such a system, which operates with communication, ceases to exist when there are no follow-up events responding to previous events. A conversation dies, an institution gets closed, a theory forgotten. To enhance the probability that communication can continue, a comprehensive description of play must therefore ensure its connective capability (for example by continuously publishing articles). However, the necessity of further communication does not imply favorable assessment: critiqueeven blunt rebuff-is an appropriate continuation for descriptive discourses.

I propose a sixth condition: the description has to bridge theory and practice. ${ }^{3} \mathrm{~A}$ description in this sense includes theory and practice: experimental methods, prototyping, play and game design practice, critique, computational models, speculative design, experiential aspects. Thus, a description can be a demonstration, an interaction and an experience. We can actually learn about play by playing.

\section{Playful Systems}

Through my PhD project "Designing Playful Systems,"4 I am developing a description of play that is abstract, complex, observer-dependent, transdisciplinary, and that bridges theory and practice (Straeubig, 2016).

In particular, I observe play through the lens of distinctions (Straeubig, 2015), based on the conceptual work of Spencer-Brown (2008), Maturana and Varela (1980) and Luhmann (1996). Distinctions serve as the universal building blocks required by the first condition. Examples are system/environment, theory/practice, human/machine, play/work or external/internal purpose.

My approach draws heavily from the foundations of Luhmann's general systems theory. While Luhmann himself focused on working out a comprehensive theory of social systems, the general principles can also be applied to psychic and biological aspects of play. In other words, the theory can provide sufficient complexity to describe every aspect of play (second condition).

\footnotetext{
${ }^{3}$ For this reason, I have used the term 'description' instead of 'theory.'

${ }^{4}$ Available at http://www.cognovo.eu/project-9
} 
Furthermore, Luhmann's theory acknowledges the fundamental role of the observer (third condition). The introduction of the observer into system-theoretic thinking took place during the second half of the last century with constructivist theories and the so-called "second-order" cybernetics (Glanville, 2002). At the price of binning notions of "objective truth," paradoxes and contradictions could be embraced from now on without an imminent collapse of the observing systems. ${ }^{5}$

In order to make sense of the multifaceted nature of play, I draw from the wide range of disciplines that have contributed to research in this area (Straeubig, Hsu, Oztop, \& Taranu, 2016) as well as from the relatively young fields of play and game studies (Mäyrä et al., 2015). This approach observes those disciplines as social systems (subsystems of academia) while re-producing its own inherent mode of observation through autopoiesis (Bishop \& Al-Rifaie, 2016). Metaphorically speaking, it provides a system-theoretic "glue" through the method of distinction (fourth condition).

At Off the Lip 2017, I gave a short talk about the topics of this paper and demonstrated a work-in-progress playful system, re-implemented from (Karpathy, 2014). The system is based on a reinforcement learning algorithm that draws distinctions from external rewards (Mnih et al., 2013). In this demonstration, theory and practice informed each other and both were exposed to the academic discourse (sixth condition). A playful system, I conclude, is one that draws distinctions for its own sake (Ghahramani, 2004), mixed with motivating rewards from the environment (Arulkumaran, Deisenroth, Brundage, \& Bharath, 2017). This will be elaborated in future work, thus contributing to the connective capability (fifth condition) of this work. This article, the discussions during the conference, the presentation I delivered, the demonstration and the responses I received-all increase the surface for communicative acts to follow.

However, a final answer to the question of whether my approach to play is "200mmett200ssfähig" has to be established in the future.

\section{Conclusion}

Currently, the problem of how we make sense of complex phenomena that span brains, minds and social systems remains unsolved. If we aim to describe cognitive innovation "from cell to society" (Gummerum \& Denham, 2014), if we want to give adequate accounts of creativity (Colton \& Wiggins, 2012), we need a framework to do so. In this article, I have proposed six requirements for any comprehensive description of these phenomena and demonstrated how I apply those principles to play.

\footnotetext{
${ }^{5}$ Pickering (2011) offers explanations why cybernetics has lost in importance over time, but I believe that the final word concerning this issue has not been spoken yet.
} 


\section{Acknowledgements}

I would like to thank François Lemarchand, Eugenia Stamboliev, Joanna "Bob" Whalley and the editors for their helpful edits and well-versed responses. I also thank the organizers of Off The Lip 2017, in particular Frank Loesche.

This work has been supported by the Marie Curie Initial Training Network FP7-PEOPLE-2013ITN, CogNovo, grant number 604764.

\section{References}

Arulkumaran, K., Deisenroth, M. P., Brundage, M., \& Bharath, A. A. (2017). A brief survey of deep reinforcement learning. Retrieved from https://arxiv.org/abs/1708.05866

Bateson, P., \& Martin, P. (2013). Play, playfulness, creativity and innovation. Cambridge, UK: Cambridge Univ. Press.

Bishop, J. M., \& Al-Rifaie, M. M. (2016). Autopoiesis in creativity and art. In MOCO '16: Proceedings of the $3^{\text {rd }}$ International Symposium on Movement and Computing. Thessaloniki, Greece: ACM. Doi:10.1145/2948910.2948948

Blassnigg, M., \& Punt, M. (2013). Transdisciplinarity: Challenges, approaches and opportunities at the cusp of history. In Steps to an Ecology of Networked Knowledge and Innovation: Enabling new forms of collaboration among sciences, engineering, arts, and design: Volume II, Meta-analyses, Abstracts, and White Papers (pp. 228-235). Cambridge, MA: MIT Press. Retrieved from http://seadnetwork.wordpress.com/draft-overview-of-areport-on-the-sead-white-papers/

Burghardt, G. M. (2005). The genesis of animal play: Testing the limits. Cambridge, MA: MIT Press.

Colton, S., \& Wiggins, G. A. (2012). Computational creativity: The final frontier? In ECAI'12: Proceedings of the 20 th European conference on artificial intelligence (pp. 21-26). ECAI12. Amsterdam, the Netherlands: IOS Press. Doi:10.3233/978-1-61499-098-7-21

Ellis, M. J. (1973). Why people play. Englewood Cliffs, NJ: Prentice-Hall.

Ghahramani, Z. (2004). Unsupervised learning. In O. Bousquet, U. von Luxburg, \& G. Rätsch (Eds.), Advanced lectures on machine learning (pp. 72-112). Berlin, German: Springer. Doi:10.1007/978-3-540-28650-9_5

Glanville, R. (2002). Second order cybernetics. In F. Parra-Luna (Ed.), Encyclopedia of life support systems (EOLSS). Oxford, UK: Eolss Publishers. Retrieved from http://www.eolss.net/

Gummerum, M., \& Denham, S. L. (2014). Cognitive innovation: From cell to society. Europe's Journal of Psychology, 10(4), 586-588. Doi:10.5964/ejop.v10i4.879

Henricks, T. (2008). The nature of play: An overview. American Journal of Play, 1(2), 157-180. Retrieved from http://www.journalofplay.org/sites/www.journalofplay.org/files/pdfarticles/1-2-article-the-nature-of-play.pdf

Huizinga, J. (1955). Homo ludens: A study of the play-element in culture. Boston, MA: The Beacon Press. 
Karpathy, A. (2014). ConvNetJS: Deep Learning in your browser. Retrieved from http://cs.stanford.edu/people/karpathy/convnetjs/

Luhmann, N. (1996). Social systems. Stanford, CA: Stanford University Press.

Luhmann, N. (2000). Art as a social system (E. Knodt, Trans.). Stanford, CA: Stanford University Press. (Original work published 1997)

Luhmann, N. (2009). Die Wissenschaft der Gesellschaft. Frankfurt am Main, Germany: Suhrkamp.

Maturana, H. R., \& Varela, F. J. (1980). Autopoiesis and cognition: The realization of the living. Dordrecht, the Netherlands: D. Reidel Publishing.

Mäyrä, F., Lammes, S., Deterding, S., Giddings, S., Consalvo, M., Mortensen, T. E., ... Jørgensen, K. (2015, May). From game studies to studies of play in society: A panel. Paper presented at the DiGRA 2015: Diversity of play: Games - Cultures - Identities, Lüneburg, Germany.

Mnih, V., Kavukcuoglu, K., Silver, D., Graves, A., Antonoglou, I., Wierstra, D., \& Riedmiller, M. A. (2013). Playing Atari with deep reinforcement learning. CoRR, abs/1312.5602. Retrieved from http://arxiv.org/abs/1312.5602

Nash, A., \& Penney, T. (2015, October). The radical productivity of play. Paper presented at the 9th international conference on the philosophy of computer games, BKT-University of Art and Design, Berlin, Germany. Retrieved from http://gamephilosophy.org/pcg2015/gamephilosophy2015.btk-fh.de/wpcontent/uploads/2015/09/NashPenney-RadicalProductivityofPlay.pdf

Pellis, S. M., Pellis, V. C., \& Bell, H. C. (2010). The function of play in the development of the social brain. American Journal of Play, 2(3), 278-296.

Pickering, A. (2011). The cybernetic brain: Sketches of another future. Chicago, IL: University of Chicago Press.

Salen, K., \& Zimmerman, E. (2003). Rules of play: Game design fundamentals. Cambridge, MA: MIT Press.

Sicart, M. (2014). Play matters. Cambridge, MA: MIT Press.

Spencer, H. (1855). The principles of psychology. London, UK: Longman, Brown, Green, and Longmans.

Spencer-Brown, G. (2008). Laws of form (5 ${ }^{\text {th }}$ ed.). Leipzig, Germany: Bohmeier.

Straeubig, M. (2015). On the distinction between distinction and division. Technoetic Arts, 13(3), 245-251. doi:10.1386/tear.13.3.245_1

Straeubig, M. (2016, August). Playing with distinctions: Towards a theory of playful systems. Paper presented at the First International Joint Conference of Digra and FDG, Dundee, UK. doi: 10.13140/RG.2.1.4057.4322 
Straeubig, M., Hsu, C.-W., Oztop, P., \& Taranu, M. (2016). (How) does play matter? A transdisciplinary approach to play and its relation to neurobiology, creativity and deception. In M. Punt, S. L. Denham, \& E. Doove (Eds.), Off the Lip: Transdisciplinary Approaches to Cognitive Innovation: Conference proceedings (pp. 215-231). Plymouth, UK: Plymouth University. Retrieved from http://pearl.plymouth.ac.uk/handle/10026.1/4271

Sutton-Smith, B. (1997). The ambiguity of play. Cambridge, MA: Harvard University Press.

Mortensen, T. E., Linderoth, J., \& Brown, A. M. L. (Eds.). (2015). The dark side of game play: Controversial issues in playful environments. New York, NY: Routledge. 